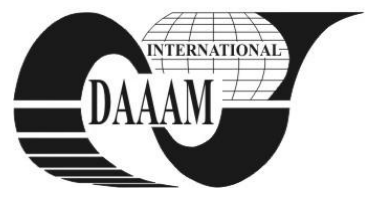

\title{
CRISIS MANAGEMENT AND HR MANAGEMENT: OVERVIEW OF IMPORTANT STUDIES AND RESEARCHES
}

\author{
BJORKLUND, K[arina]
}

\begin{abstract}
The aim of this article was to describe current situation in researches and studies concerning crisis management and human resource management. It was found that the history of studies and researches on selected field is long. At the same time these are not connected. Author aims to focus among other tasks also on covering this gap during author's further activities
\end{abstract}

Key words: crisis management, HR management, human resource, employee representative, overview

\section{INTRODUCTION}

Crisis management and human resource (HR) management, including employee representation issues, both are wide fields and both have long history of studies and researches. During years of researches a lot of studies were done, many practically applicable and only theoretical models were built. Author aim is to analyse IT enterprises, this is why some approaches handled in this paper are technical and related to information technology.

The majority of the literature examined additionally to the number of useful models and approaches showed that those areas are pretty rarely researched together.

The aim of this article was to make overview of so far proceeded the most important researches and studies. Such kind of summary over the time is necessary to see future possibilities and gaps in current situation.

Proceeded research gave important conclusion to the author and helped to plan future possibilities on chosen area. Using the achieved results, author plans to connect crisis management and HR management.

Further paragraphs give the description of the most important studies and researches concerning crisis management and HR management. At the end, the conclusion is done.

\section{OVERVIEW OF LITERATURE CONCERNING CRISIS MANAGEMENT}

The overview of literature concerning crisis management is presented in this paragraph. The overview's structure is organized according the approaches that are the most important for the authors.

Crisis management can be analysed from theoretical point of view - from here comes also the first handled approach: theoretical approach. In this case all assumptions, theories and conclusions are based on theory and may be not applicable in practice.

More practical approach is model development. Most of the models that are well-known currently are linear and life-cycle models. One example of such model is frequently cited four stage model of Fink (Fink, 1986). At the same time, more efficient crisis management process is such process, where several activities might be processed in parallel. To such conclusion came also Jaques during his researches on crisis management modelling (Jaques, 2007). Jaques presented his relational model and presented case studies that proved his model usefulness.

Another approach of researching crisis management is to classify crises. As well as modelling, classification was started long ago and is popular activity nowadays. Crisis classification usually leads to naming 4-7 different crisis types and giving main properties and options of them.

\section{OVERVIEW OF LITERATURE CONCERNING HUMAN RESOURCE MANAGEMENT}

The overview of literature concerning human resource management is presented in this paragraph. The overview's structure is organized according the approaches that are the most important for the authors. During researches of HR management issues, two main areas were analysed: pure HR and employee representation.

The reason why these areas were separately analysed is because these two areas are researched separately from each other.

At first, pure HR area literature is observed. There are four main approaches that are used by the researches of this field: 1) technical approach, 2) people- and organization-centred approach, 3) BPR (Business Process Reengineering), 4) ERP (Enterprise Resource Planning).

These are presented here in order of their historical appearance. As author's objective is related to information technology, then the first analysed approach was technical. The history of this approach is long and researches and innovations are still in progress.

Another wide approach is people- and organization-centred approach. It is well represented by Mumford, who defined ETHICS approach (Mumford, 1996).

Other two approaches are related to planning. One of them is BPR (Business Process Reengineering), second in ERP (Enterprise Resource Planning). In case of both approaches software programs are used for smoothing planning activities. If ERP related works are mainly practical and describe software integration and usage, then BPR related studies are of both types - practical and/or theoretical. BPR approach main researcher (and also developer) is Hammer, who either alone or together with Champy analysed BRP approach by proposing new ways of thinking (Hammer \& Champy, 1993) and further works.

A separate place in literature overview took analysis of studies regarding employee representation. Most works regarding this area have one of these statements to prove if employee representation is needed or not.

There are no remarkable approaches for studying this issue. If not talking about the need of employee representation, then researchers were writing about the terminology problem. Named problem has a huge meaning and importance, because it is not possible or pretty hard to make any researches if related 
literature is difficult to find. And it is really hard to find needed literature, if area terminology is not fixed and one issue can be named by using many different combinations of words.

But what needs separate remarking is that very fewer studies combine HR management and employee representation issues - most researches are limited to either of areas. The reason for this is that appearing of the employee representation as a separate area was an evolution step of HR management. That is why dealing with both areas is too wide and usually researches tend to focus on either of the areas. One of the first researches who wrote about the employee representation as a part of HR management was Lawler (Lawler, 1977).

\section{OVERVIEW OF RESEARCH METHODS}

Mostly used research methods are: interviews, case studies, correlational studies, experimental designs, and questionnaires. Need of using experimental designs (in addition to case and correlational studies) was described by Lawler, (Lawler, 1977).

Concerning questionnaires no common approach was used - some researchers used their own. Usually in this case some hypotheses were stated at first. According to those questions were written down. Questionnaire results either proved, or disproved stated hypotheses.

Some researchers used known and accepted questionnaires (another way was to take accepted questionnaire and update it according to ones needs). For example, during their research of crisis management, Spillan, J. and Hough, M. (Spillan \& Hough, 2003) used a questionnaire developed by Crandall et al. (Crandall et al., 1999).

Also reusing of once used own questionnaires was present. This approach is good from the point of view that situation can be checked after some time. This means that if attitude to the same issue changes during the time, then it will be noticed and reported.

Some research aspects may be hidden from researcher and therefore different behaviour styles are not observable if researcher starts with purely quantitative methods. Dependencies inside company may vary in different enterprises. Qualitative researches might help better understand the essence of phenomena. That is why these or not purely quantitative researches were used.

That means that more deep analysis of interdependencies inside the company is particularly important for understanding the phenomena. Coding analysis of interviews with company employees which helps to understand what keywords and definitions respondents use for describing their vision and understanding the phenomena is useful for business research. Moreover coding analysis is able to describe the nature of issues respondents associate with the phenomena. Besides, QDA is essential for revealing and visualizing keywords that respondents use. Example of authors who used this method is Marchington et al. (Marchington et al., 1994).

At first, researches started with quantitative research (mostly using interviews with or without video recording). As the result, more accurate questionnaires could be set up. The second phase of the research was quantitative research using those questionnaires.

Another issue about the research methods connected to the given subject is the field definitions. That means personnel in the representative sample of enterprises uses a lot of different slang or words for naming one issue or under one definition understood totally different meanings. For example, this problem related to difference in interpreting of used term was described and researched by Xi Liu et al. (Xi Liu et al., 2009).

\section{CONCLUSION}

Analysis of the various studies connected to crisis and HR management, including employee representation issues, gives an opportunity to find out, what was done in the subject so far.

Crisis subject researchers wrote about the stages and composed different models to represent this phenomenon. There are works where author discusses what can be done to fight the crisis situation, stressed is the importance of crisis management plan existence. Usually big enterprises are under consideration, rarely SMEs are under research.

Human resource management, which is one of the biggest sections in crisis management plan, was researched by many people. Usually HR management is under research under normal circumstances, while it could be watched also together with crisis management, as part of this big process.

Another option in HR management is employee representation during the process. This issue was under research during long time, but without big popularity. The main outcome that was found by the researchers is that enterprise management understands employees' voice and representation in their own way. This means that management as well as other employees are not educated well from this point of view. Secondly, there is different employees' attitude to the situation in their company depending on one's position. So, this fact should be taken into account while electing employees' representatives.

The numbers of researches propose methods for solving problems in organisations via HR management and describe the situation on employees' voice representation. But the fact is that those issues are rarely handled in combination with crisis and crisis management, as numerous researches were made purely for crisis management issues. Hence, this is the area which needs some additional researches and investigations. Author states that it is important to research crisis management phenomena on a concrete sight of HR management and employee voice usage. Author's further researches will concentrate on found uncovered areas using popular research tools by updating those or using own research tools.

\section{REFERENCES}

Crandall, W., McCartney, M. \& Ziemnowicz, C. (1999). Internal auditors and their perceptions of crisis events. Internal Auditing, Vol. 14, No. 1, 11-17

Fink, S. (1986). Crisis management: Planning for the inevitable, American Management Association, ISBN: 0814458599, New York

Hammer, M. \& Champy, J. (1993). Reengineering the Corporation: A Manifesto for Business Revolution, Harper Business Books, ISBN: 0066621127, New York

Jaques, T. (2007). Issue management and crisis management: An integrated, non-linear, relational construct. Public Relations Review, Vo.l 33, No. 2 (2007) 147-157, ISSN: 0363-8111

Lawler III, Edward E. (1977). Adaptive Experiments: An Approach to Organizational Behavior Research. Academy of Management, Vol. 2, No. 4 (Oct., 1977) 576-585, ISSN: 0363-7425

Marchington, M., Wilkinson, A., Ackers, P. \& Goodman, J. (1994). Understanding the meaning of participation; views from the workplace. Human Relations, Vol. 4, No. 8 (1994) 867-894, ISSN: 0018-7267

Mumford, E. (1996). Systems Design: Ethical Tools for Ethical Change, Macmillan Press, ISBN: 0333669460, UK

Spillan, J., \& Hough, M. (2003). Crisis Planning in Small Businesses: Importance, Impetus and Indifference. European Management Journal, Vol. 21, No. 3 (2003) 398-407, ISSN: 0263-2373

Xi Liu, Zhuo Chang, Ping Zhao. (2009). Is it simply a matter of managerial competence? Interpreting Chinese executives' perceptions of crisis management. Public Relations Review, Vol. 35, No. 3 (Sept., 2009) 232-239, ISSN: 0363-8111 